\title{
NANDA International nursing diagnoses in patients admitted to a medical clinic unit
}

\author{
Diagnósticos de enfermagem da NANDA Internacional em pacientes internados em unidade \\ de clínica médica
}

Isabela Ubaldo $^{1}$, Eliane Matos ${ }^{1}$, Nádia Chiodelli Salum ${ }^{1}$, Juliana Balbinot Reis Girondi ${ }^{1}$, Lícia Brito Shiroma ${ }^{1}$

Objective: to identify nursing diagnoses, their defining characteristics and related factors, according to the NANDA-International diagnostic classification (2012-2014). Methods: a quantitative study that used as a sample 134 medical records of patients admitted to a university hospital. The analysis was based on descriptive statistics: frequency and percentage. Results: the most prevalent nursing diagnoses are in the areas of coping/stress tolerance, safety/protection and comfort. The following are the diagnoses of: risk of infection (93.8\%), impaired skin integrity risk (60.4\%) and anxiety (60.4\%). There was a significant variation in the interpretation of the same diagnosis in relation to the defining characteristics and related factors identified. Conclusion: diagnoses presented in the research are among the most frequent in hospitalized patients with clinical intercurrences.

Descriptors: Nursing Diagnosis; Nursing Records; Nursing.

Objetivo: identificar os diagnósticos de enfermagem, suas características definidoras e fatores relacionados, segundo a classificação diagnóstica da NANDA-Internacional (2012-2014). Métodos: estudo quantitativo que utilizou como amostra 134 prontuários de pacientes internados em um hospital universitário. A análise se deu mediante estatística descritiva: frequência e percentual. Resultados: os diagnósticos de enfermagem mais prevalentes encontram-se nos domínios enfrentamento/tolerância ao estresse, segurança/proteção e conforto. Destacam-se os diagnósticos de: Risco de infecção (93,8\%), Risco de integridade da pele prejudicada (60,4\%) e Ansiedade (60,4\%). Houve significativa variação de interpretação de um mesmo diagnóstico em relação às características definidoras e fatores relacionados identificados. Conclusão: diagnósticos apresentados na pesquisa estão entre os mais frequentes em pacientes internados com intercorrências clínicas.

Descritores: Diagnóstico de Enfermagem; Registros de Enfermagem; Enfermagem.

${ }^{1}$ Universidade Federal de Santa Catarina. Florianópolis, SC, Brazil.

Corresponding author: Eliane Matos

Rua Prof. Ayrton Roberto Oliveira, 20, apto 302A. CEP: 88034050 - Itacorubi. Florianópolis, SC, Brazil. E-mail: elianematos@hotmail.com 


\section{Introduction}

The Systematization of Nursing Care became mandatory in Brazil as of 2009, through Resolution $358 / 2009$ of the Federal Nursing Council ${ }^{(1)}$, and is understood as the use of method and strategy of scientific work to identify situations of health/illness, which support Nursing care and contribute to the promotion, prevention, recovery and rehabilitation of patient, family and community health.

The Nursing Assistance Systematization organizes the professional work on the method, personnel and instruments, making possible the operationalization of the Nursing process, which is structured in five stages: nursing history, nursing diagnosis, nursing planning, implementation and evaluation of nursing. The nursing process, in turn, is understood as the methodological instrument guiding nursing care and documentation of professional practice ${ }^{(1)}$.

As part of the nursing process, the nursing diagnosis is an important nursing research topic in terms of nursing assessment quality, interventions and results, as well as facilitating communication and continuity of care ${ }^{(2)}$. This is a fundamental step in the planning of nursing care or prescription and Identification of the patient's actual or potential health problems with their particular characteristics, ie, in an individualized way, using scientific reasoning ${ }^{(3)}$. The nursing diagnosis is the basis for the selection of nursing interventions, in order to reach the expected results with nursing $\operatorname{care}^{(4)}$.

The use of the term nursing diagnosis is still recent, both in Brazil and in the international context. The first conference was created in 1973 with the aim of creating a diagnostic classification system compatible with computer science; And it was from this conference that nurses from Canada and the United States created the National Group for the Classification of Nursing Diagnosis in 1982 named then North American Nursing Diagnosis Association (NANDA) ${ }^{(4)}$. In 1980 the American Nurses Association defines nursing as a science capable of diagnosing and treating human responses to potential and real health proble$\mathrm{ms}^{(5)}$.

Known worldwide, NANDA International (NANDA-I) has been used in Brazil, associated to the theory of Basic Human Needs ${ }^{(6)}$. In the institution under study, Nursing Care Systematization is based, since 1980, on the reference framework of Basic Human Needs ${ }^{(6-7)}$. However, it does not incorporate in the process the stage of nursing diagnosis, stopping to register the patient's problems for the planning of care. The present study is justified considering the importance of the diagnostic stage for nursing care planning and the diversity of pathologies of patients admitted to the medical units of the studied institution, which can benefit from quality and individualized care, made possible by the nursing diagnosis.

Understanding that nursing diagnosis is an important part of care systematization, the study aimed at identifying nursing diagnoses, their defining characteristics and related factors, according to the NANDA-I diagnostic classification (2012-2014).

\section{Methods}

This is a non-probabilistic, cross-sectional, observational study carried out in a medical clinic unit of the University Hospital of southern Brazil, which uses the Nursing Care Systematization, according to the Basic Human Needs model ${ }^{(6)}$ for the planning of care of the hospitalized patients.

In this institution, Nursing Care Systematization is developed based on the nursing history carried out during the first 24 hours of the patient's hospitalization, in which nursing problems are identified. For these problems, nursing care is prescribed. Once the nursing prescription has been performed, in the daily evolution of nursing, the evaluation of the clinical condition of the patient and the response of the patient to the nursing care are made. The prescription is then updated according to the patient's condition. The nursing diagnosis stage corresponds to the identification of the problems/needs and to the establishment of the 
degree of dependence of the patient ${ }^{(6)}$; this step is not adopted in the institution.

Eight nurses from the medical clinic unit were participants in the collection to identify the Nursing Diagnostics. The identification of the diagnoses was performed by the nurses during the history of the patient and afterwards, they were reassessed, modified, maintained or added with new diagnoses in the daily performance of the nursing evolution.

Data collection took place for 60 days, in June and July 2012, during which 134 patients with various pathologies were admitted to the study unit. The nurses performed 1223 nursing processes involving these patients. In 994 of the evaluated processes the Nursing Diagnosis was included as part of it. At the beginning of the research the nurses chose to work with 8 diagnoses that they understood to be the most frequent in the reality to be studied. At the beginning of the research process, however, they realized the need to include three other diagnoses, therefore, 11 NANDA-I Classification Nursing Diagnoses were developed. The eight diagnoses listed initially for the study were: chronic pain, ineffective respiratory pattern, impaired skin integrity, impaired skin integrity risk, impaired tissue integrity, anxiety, risk of infection, and unstable glycemic risk. These 8 diagnoses were analyzed in relation to total medical records. Subsequently, the diagnoses of unbalanced nutrition were incorporated: less than the body needs, constipation and risk of constipation. This second group of diagnoses was analyzed in relation to 69 records of the total of 134 that were part of the study.

To carry out the study, the eleven nursing diagnoses with their defining characteristics and related factors/risks were included in the computerized application of the Systematization of Nursing Care, already in use at the institution, and the nurses were instructed to use it. The nurses' registry was evaluated daily by one of the researchers.

The Nursing Diagnoses were organized in an excel spreadsheet, systematically updated during data collection, for further analysis. In the analysis of the data, the simple frequencies of identification of each diagnosis were observed, these being tabulated through absolute frequency and percentage.

The medical records of all patients hospitalized during the study period were analyzed, i.e., 134 patients (medical records), of which in 129 nursing diagnoses were identified. Daily records were considered in each of the medical records, and the same medical record was evaluated more than once, depending on the length of hospital stay.

The study complied with the formal requirements contained in the national and international regulatory standards for research involving human beings.

\section{Results}

The results indicate an important nursing adhesion to the Nursing Care Systematization, which is performed daily for each of the patients hospitalized in the unit studied. It was verified that the nursing history, prescription and nursing evolution stages were routinely performed, and that the nursing diagnosis was no longer recorded in 5 of the 134 charts analyzed.

In the analysis of the percentage of occurrence of nursing diagnoses in the patients hospitalized at the Clinical Medical Units studied, it was observed that of 129 medical records: 121 (93.2\%) had a diagnosis of infection risk; 78 (60.4\%) presented diagnoses of impaired skin integrity risk and anxiety; 65 (59.4\%) unstable glycemia risk; 55 (42.6\%) impaired skin integrity; 34 (26.4\%) chronic pain; 33 (25.5\%) ineffective respiratory pattern and 30 (23.3\%), impaired tissue integrity.

The diagnoses of unbalanced nutrition: less than the bodily needs; risk of constipation and constipation evaluated in 69 charts, obtained the following percentages of frequency: $31(44.0 \%)$ presented a diagnosis of unbalanced nutrition: less than the bodily needs; 22 (31.8\%) had a risk of constipation and 14 $(20.2 \%)$ had a diagnosis of constipation. 
Evaluating the nursing diagnoses together with the related factors, it was obtained that the risk of infection with 287 occurrences was related to invasive procedures in 107 (37.2\%) situations, increased environmental exposure to pathogens in $80(27.8 \%$ $\%)$, Chronic disease 40 (14\%), tissue destruction 37 $(13.0 \%)$ and other risk factors in $23(8.0 \%)$.

Risk of impaired skin integrity, present in 237 occurrences, was related to physical immobility 41 (17.4\%); extremes of age 38 (16.0\%); mechanical factors 31 (13.0\%); bone prominences 19 (8.0\%) and other risk factors 108 (45.6\%). Impaired skin integrity with 102 occurrences was related to mechanical factors 36 (35.2\%); physical immobilization 11 (10.7\%); extremities of age 8 (7.8\%) and other related factors 47 (46.0\%). Of the 39 occurrences of impaired tissue integrity, 16 (41.0\%) were related to the altered circulation; 9 (23.0\%) to mechanical factors and $14(35.9 \%)$ to other related factors.

The diagnosis of unstable glycemia risk with 107 occurrences was related to 45 (42.0\%); food intake 9 (8.4\%); control of drugs 31 (28.9\%); other risk factors $22(20,5 \%)$.

Risk of constipation present in 34 situations was related to the change in usual eating patterns 9 (26.4\%); irregular evacuation habits 4 (11.7\%); mental confusion 3 (8.8\%); poor dietary habits 3 (8.8\%) and other risk factors 15 (44.1\%). Constipation with 26 occurrences was related to the change in dietary patterns 4 (15.3\%); poor eating habits 3 (11.5\%); recent changes in environment $3(11.5 \%)$ and other related factors 16 (61.5\%).

The diagnosis of anxiety with 114 occurrences was related to threat to health status 44 (38.6\%); anxiety 24 (21.0\%); stress $12(10.5 \%)$ and other related factors 34 (29.8\%).

Chronic pain with 35 occurrences was related, chronic physical disability 33 (94.2\%) and chronic psychosocial disability 2 (5.7\%).

Regarding the diagnosis of ineffective respiratory pattern with 57 occurrences, it was related to respiratory muscle fatigue 14 (24.5\%); Neuromuscular dysfunction 13 (22.8\%); Musculoskeletal damage 13 (22.8\%) and other related factors 17 (29.8\%).

Unbalanced Nutrition, less than the bodily needs, was identified in 36 (58.3\%) nursing processes. Twenty-one $(58.3 \%)$ of the evaluations were related to biological factors; in 8 (22.2\%) to impaired food intake capacity and 7 (19.4\%) to other related factors.

Regarding skin integrity diagnoses, Table 1 shows the occurrences of defining characteristics:

Table 1 - Occurrence of the defining characteristics of the nursing diagnoses of impaired skin integrity and impaired tissue integrity in medical clinic

\begin{tabular}{lcc}
\hline Defining characteristics & n (\%) & $\begin{array}{c}\text { Confidence } \\
\text { Intervals 95\% }\end{array}$ \\
\hline Impaired skin integrity & & \\
Skin surface breakdown & $31(36.0)$ & $26.6-45.5$ \\
Invasion of body structures & $26(30.2)$ & $21.2-39.2$ \\
Destruction of the skin layers & $25(29.1)$ & $20.2-38.0$ \\
Other defining characteristics & $4(4.7)$ & $0.5-8.8$ \\
Total & $86(100.0)$ & \\
Impaired tissue integrity & & \\
Injured tissue & $28(77.8)$ & $69.6-85.9$ \\
Destroyed tissue & $8(22.2)$ & $14.1-30.4$ \\
Total & $36(100.0)$ & \\
\hline Source: Adapted & \\
& & \\
\hline
\end{tabular}

In addition to these, unbalanced nutrition, less than bodily needs, was characterized by lack of interest in food 13 (22.4\%); report of inadequate food intake, lower than the recommended daily portion 11 (18.9\%); aversion to eating 7 (12.0\%); perceived inability to eat food 6 (10.3\%); abdominal pain $6(10.3 \%)$ and other defining characteristics 15 (25.8\%), totaling 58 occurrences.

Constipation was characterized by inability to eliminate feces 9 (30.0\%); distended abdomen $6(20.0 \%)$ and other defining characteristics 15 (50.0\%), totaling 30 occurrences.

Table 2 below shows the defining characteristics of the diagnoses of anxiety, chronic pain and ineffective respiratory pattern. 
Table 2 - Occurrence of defining characteristics according to nursing diagnoses anxiety, chronic pain and ineffective respiratory pattern in patients admitted to the medical clinic service

\begin{tabular}{lcc}
\hline Defining characteristics & $\mathbf{n}(\mathbf{\%})$ & $\begin{array}{c}\text { Confidence } \\
\text { Intervals 95\% }\end{array}$ \\
\hline Anxiety & & \\
Apprehensive & $54(16.2)$ & $9.0-23.4$ \\
Worried & $50(15.0)$ & $8.0-22.0$ \\
Anxious & $38(11.4)$ & $5.2-17.6$ \\
Other defining characteristics & $191(57.4)$ & $47.7-67.1$ \\
Total & $333(100.0)$ & \\
Chronic pain & & \\
Verbal report of pain & $30(39.0)$ & $29.4-48.5$ \\
Facial expression & $15(19.5)$ & $11.7-27.2$ \\
Other defining characteristics & $32(41.6)$ & $31.9-51.2$ \\
Total & $77(100.0)$ & \\
Ineffective respiratory pattern & & \\
Dyspnea & $29(43.3)$ & $33.6-53.0$ \\
Use of accessory muscles to breathe & $11(16.4)$ & $9.2-23.7$ \\
Changes in respiratory depth & $9(13.4)$ & $6.7-20.1$ \\
Tachypnea & $7(10.4)$ & $4.5-16.4$ \\
Other defining characteristics & $11(16.4)$ & $9.2-23.7$ \\
Total & $67(100.0)$ & \\
\hline Source: Adapted ${ }^{(8)}$ & & \\
\hline
\end{tabular}

Finally, the study identified the predominant diagnostic statement. Anxiety assessed in 374 situations was related in 35 (9.3\%) of the cases to the threat to health status and was characterized by the condition of concern; 31 (8.2\%) related to the threat to the state of health and characterized as apprehensive; 308 (82.3\%) related to other factors and characterized by other defining characteristics.

Regarding the diagnosis of risk of infection of 287 occurrences, 107 (37.2\%) were related to invasive procedures and 18 (62.7\%) were related to other risk factors. Risk of impaired skin integrity, with 237 evaluations, was related to physical immobility in 41 (17.3\%) of the cases and $196(82.7 \%)$ to other risk factors. Of the 107 cases of the diagnosis of unstable glycemic risk, 45 (42\%) were related to physical health status and 62 (57.9\%) to other risk factors.
From 101 evaluations of impaired skin integrity, 23 (16.5\%) were related to mechanical factors and were characterized by invasion of body structures; $15(10.7 \%)$ to mechanical factors characterized by rupture of the skin surface, and 101 (72.6\%) to other related factors and other defining characteristics. Ineffective respiratory pattern, present in 86 evaluations was related to respiratory muscle fatigue and characterized by dyspnea in 13 (15.1\%) cases; for neuromuscular dysfunction characterized by dyspnea in $12(13.9 \%)$ and other related factors characterized by other defining characteristics in 61 (70.9\%).

The nursing diagnosis chronic pain with 74 occurrences was related to chronic physical incapacity characterized by verbal report of pain in 29 (37.6\%) cases; for chronic physical disability characterized by facial expression in 14 (18.1\%) and other related factors characterized by other defining characteristics in $34(44.1 \%)$ of the cases.

Unbalanced Nutrition: less than the body needs related to biological factors appeared in 21 situations, that is, $9(14.5 \%)$ characterized by lack of interest in food, $6(9.6 \%)$ due to abdominal pain and $6(9,6 \%)$ due to reports of inadequate food intake, lower than the RDP. The same diagnosis is associated with other related factors and other defining characteristics in 41 (66.1\%) of the nurses' evaluations, totaling 62 occurrences.

Regarding the impaired tissue integrity of the 48 occurrences, 15 (31.2\%) were related to the altered circulation and characterized by damaged tissue; 9 (18.7\%) were related to mechanical factors and characterized by damaged tissue; And 24 $(50.0 \%)$ to other related factors and other defining characteristics.

The diagnosis of constipation was related to recent changes in the environment and characterized by inability to eliminate feces 3 (7.8) and distended abdomen 2 (5.2\%); Changes in dietary pattern were characterized by distended abdomen 2 (5.2\%), inability to eliminate feces $2(5.2 \%)$ and decreased frequency 2 (5.2\%). Still, constipation related to 
insufficient physical activity was characterized by the inability to eliminate feces 2 (5.2\%); deficient eating habits characterized by the inability to eliminate feces $2(5.2 \%)$ and other related factors characterized by other defining characteristics 23 (60.5\%), totaling 38 evaluations. When assessing the risk of constipation in 34 situations, $9(26.4 \%)$ were related to physical health status and $25(73.5 \%)$ were related to other risk factors.

\section{Discussion}

The study points to the diagnosis of infection risk as one of the most frequent in the medical clinic studied, this finding was frequently related to the existence of invasive procedures, in most cases due to the need to maintain venous access for medication administration. Identifying the risk of infection early and correctly is a safety factor for the patient. As nurses demonstrate their concern about this aspect of care, they may diagnose and predict interventions for these patients, contributing to the safety and quality of nursing care. Preventing preventable infection is the role of every professional concerned with individual and collective health.

Another important finding relates to the risk of impaired skin integrity. The diagnosis was interpreted as a result of hospitalization, clinical conditions and medical diagnoses, besides the high degree of patient dependency and increased propensity for skin lesions, either by age or by confinement to the bed, leading to the development of pressure ulcers.

The high incidence of this diagnosis indicates the concern of the nurses to provide care to ameliorate and/or avoid the risk. Similar results were found in another study with intensive care patients in which $100.0 \%$ of the patients were diagnosed as having impaired skin integrity. Age, immobility, mechanical factors, chronic disease and invasive procedures are pointed out in the study as factors related to this diagnosis, showing similarity with the findings in this study ${ }^{(9)}$. Corroborating the data of this and other stu- dies, it is known that the aging population is reflected in an increase in the percentages of hospitalization of the elderly. Research with the objective of identifying nursing diagnoses formulated for elderly patients in a health institution found that the prevalent nursing diagnoses were risk of infection (78.0\%), impaired physical mobility (69.0\%) and risk for integrity of the impaired skin $(59.0 \%)^{(10-11)}$.

The diagnosis of chronic pain may be related to the profile of the patients, usually with chronic pathologies. It is important to emphasize the importance of the defining characteristics of pain to reach the nursing diagnosis chronic pain ${ }^{(4)}$. This data differs from a survey performed in a hospital in a medical clinic, in which the predominant pain diagnosis was characterized as an acute condition and occurred in $66.7 \%$ of the sample studied ${ }^{(4,11)}$. In the definition of NANDA-I, the concepts of chronic and acute pain differ only in duration (more or less than six months respectively) and in the prediction of its resolution. Acute pain allows predicting its end, as opposed to chronic pain ${ }^{(4)}$.

Unbalanced Nutrition diagnoses: less than body needs, risk of constipation and constipation can be analyzed in relation to research done with elderly people at home ${ }^{(12)}$, in which nursing diagnostics of the nutrition domain were studied. In the study it was verified that the diagnosis of nursing unbalanced nutrition, less than the bodily needs, was present in $32.7 \%$ of the elderly patients, being associated with the changes in the organism, motivated by the aging process and the deficient intake.

In only four cases no nursing diagnoses listed for the study were found. The medical clinic units assist, mostly, chronic patients, and, in general, dependents of nursing care ${ }^{(13)}$.

Finally, the majority of the diagnoses and consequently of nursing care were determined in physiological health standards and few in psychosocial standards, a result that corroborates a study carried out in Dutch hospitals ${ }^{(14)}$ and also in a study carried out in a Brazilian hospital with urological patients ${ }^{(15)}$.

The results of the research and the differences 
in the interpretation of the related factors and defining characteristics, interfering in the definition of the diagnoses are a limitation of the study. At the same time it signals the inexperience and lack of mastery of nurses with this classification and the need for professional qualification. Nursing Diagnoses are fundamental to guide nursing interventions.

\section{Conclusion}

The study brought the main nursing diagnoses, their defining characteristics and related factors, placing them in the domains of safety/protection, coping/ tolerance, regulation, comfort, rest/activity, nutrition elimination and change in the domain of physical lesion, coping reactions, metabolism, physical comfort, cardiovascular/pulmonary responses, ingestion and gastrointestinal function. These diagnoses are representative of nursing care for patients attending a medical clinic and the knowledge about them, with the introduction of the NANDA-I diagnostic classification to reality, makes an important contribution to nursing knowledge and professional practice documentation.

\section{Collaborations}

Ubaldo I and Matos E contributed to the project design, collection, organization, analysis and interpretation of the data, writing of the article and final approval of the version to be published. Salum NC, Girondi JBR and Shiroma LB contributed in the analysis and interpretation of data and relevant critical review of the article.

\section{References}

1. Conselho Federal de Enfermagem (BR). Resolução no 358, de 23 de outubro de 2009. Dispõe sobre a Sistematização da Assistência de Enfermagem e a implementação do Processo de Enfermagem em ambientes, públicos ou privados, em que ocorre o cuidado profissional de Enfermagem, e dá outras providências. Brasília: Conselho Federal de Enfermagem; 2009.
2. Frigstad SA, Nøst TH, André B. Implementation of free text format nursing diagnoses at a University Hospital's Medical Department. Exploring nurses' and nursing students' experiences on use and usefulness. A qualitative study. Nurs Res Pract [Internet]. 2015 [cited 2016 Mai 3]; 2015. Available from: http://dx.doi.org/10.1155/2015/179275

3. Bittencourt GKGD, Crossetti MGO. Critical thinking skills in the nursing diagnosis process. Rev Esc Enferm USP. 2013; 47(2):341-7.

4. North American Nursing Diagnosis Association NANDA International. Diagnósticos de enfermagem da NANDA: definições e classificação 20152017. Porto Alegre: Artmed; 2015.

5. Doenges ME, Moorhouse MF, Murr AC. Diagnósticos de enfermagem: intervenções, prioridades, fundamentos. Rio de Janeiro: Guanabara-Koogan; 2011.

6. Horta WA. Processo de enfermagem. São Paulo: EPU; 2010.

7. Ubaldo I, Matos E, Salum NC, Girondi JBR. Diagnósticos de enfermagem da NANDA-I com base nos problemas segundo teoria de Wanda Horta. Cogitare Enferm. 2015; 20(4):687-94.

8. Ubaldo. I. O diagnóstico de enfermagem da NANDA internacional na sistematização da assistência de enfermagem na clínica médica de um hospital universitário. Dissertação (mestrado) - Universidade Federal de Santa Catarina. Florianópolis, 2013.

9. Lima APS, Chianca TCM, Tannure MC. Assessment of nursing care using indicators generated by software. Rev Latino-Am Enfermagem. 2015; 23(2):234-341.

10. Araújo DD, Carvalho RLR, Chianca TCM. Nursing diagnoses identified in records of hospitalized elderly. Invest Educ Enferm. 2014; 32(2):225-35.

11. Nogueira GA, Oliveira BGRB, Santana RF, Cavalcanti ACD. Nursing diagnoses in patients with chronic venous ulcer: observational study. Rev Eletr Enf. [Internet]. 2015 [cited 2016 Ago 01];17(2):3339. Avaliable from: http://dx.doi.org/10.5216/ree. v17i2.28782 
12. Clares JWB, Freitas MC. Diagnósticos de enfermagem do domínio nutrição identificados em idosos da comunidade. Rev Eletr Enf. [Internet]. 2013 [cited 2016 Ago 01];15(4):940-7. Disponível em: https://www.fen.ufg.br/fen_revista/v15/n4/ pdf/v15n4a11.pdf

13. Brito AP, Guirardello EB. Nível de complexidade assistencial dos pacientes em uma unidade de internação. Rev Bras Enferm. 2012; 65(1):92-6.
14. Paans W, Muller- Staub M. Patients' Care Needs: documentation analysis in general hospitals. Int J Nurs Knowl. 2014; 26(4):178-86.

15. Lima WG, Nunes SFL, Alvarez AM, Valcarenghi RV, Bezerra MLR. Main nursing diagnoses in hospitalized elderly people who underwent urological surgery. Rev Rene. 2015. 16(1):76-80. 